\title{
DATA WAREHOUSE, DATA MINING DAN KONSEP CROSS-SELLING PADA ANALISIS PENJUALAN PRODUK
}

\author{
Eka Miranda; Natalya Elfreida \\ Jurusan Sistem Infromasi, Fakultas Ilmu Komputer, Bina Nusantara University \\ Jln. K.H. Syahdan No.9, Palmerah, Jakarta Barat 11480 \\ ekamiranda@yahoo.com,natalya_3a2@yahoo.co.id
}

\begin{abstract}
This paper is about designing and implementing data warehousing and data mining, along with their roles in supporting decision-making related to sales product analysis in cross-selling concept of PT XYZ. The database the company used is not supporting data analysis and decision-making. Therefore, it made a data warehousing design that could be used to keep data in a huge amount and could give report and answer from user's questions in ad hoc. The method is used to design and implement data warehousing and data mining which consists of literature study, company problem analysis, and data warehousing design, and testing result. The writing results are a data warehousing design and data mining and also the implementation of cross-selling concept to analysis the sales, purchases, and customers' cancellation data. The data could be showed and analyzed from some point of views that could help managers to analyse and acknowledge more information.
\end{abstract}

Keywords: decision, cross-selling, data warehousing, data mining.

\begin{abstract}
ABSTRAK
Tulisan ini membahas mengenai rancangan dan implementasi data warehouse dan data mining serta peranannya dalam mendukung pengambilan keputusan yang terkait dengan analisis penjualan produk dengan konsep cross-selling pada PT XYZ. Database yang digunakan perusahaan saat ini tidak mendukung analisa data dan pengambilan keputusan. Berdasarkan permasalahan ini maka dibuat desain data warehouse yang dapat digunakan untuk menyimpan data dalam jumlah besar dan memungkinkan untuk memberikan pelaporan dan jawaban dari pertanyaan pengguna yang bersifat ad hoc. Metode yang digunakan untuk desain dan implementasi data warehouse dan data mining terdiri dari studi literatur, analisis permasalahan perusahaan, perancangan data warehouse, dan pengujian hasil. Hasil dari tulisan ini berupa desain data warehouse dan data mining serta implementasinya dengan konsep cross-selling untuk menganalisis data penjualan, pembelian dan pembatalan oleh pelanggan. Data tersebut dapat ditampilkan dan dianalisis dari beberapa sudut pandang yang berbeda, yang dapat membantu manager untuk menganalisis dan menggali lebih banyak lagi informasi.
\end{abstract}

Kata kunci: keputusan, cross-selling, data warehouse, data mining 


\section{PENDAHULUAN}

\section{Latar Belakang}

Dalam pengelolaan basis data (database) organisasi baik organisasi bisnis maupun organisasi non profit terdapat istilah bahwa organisasi kaya akan data, tetapi miskin akan informasi atau businesses have been rich in data and poor in information. Data warehouse bukan hanya suatu arsip atau fasilitas penyimpanan data, data warehouse harus dengan cerdas dirancang untuk berisi informasi dan data yang penting untuk mendukung memecahkan masalah secara aktif. Data warehouse dikembangkan untuk mempertemukan suatu permintaan bagi Manajemen Informasi dan Analisa yang tidak bisa dijumpai pada basis data. Aplikasi basis data tidak mampu untuk mempertemukan kebutuhan ini untuk beberapa pertimbangan: Pengolahan pelaporan data yang banyak/besar dapat mengurangi waktu tanggap aplikasi basis data, Perancangan aplikasi basis data tidaklah dioptimalkan untuk analisa informasi dan pelaporan, Kebanyakan organisasi mempunyai lebih dari satu aplikasi basis data, maka pelaporan secara keseluruhan organisasi tidak bisa didukung dari sistem tunggal, pengembangan laporan pada aplikasi basis data sering memerlukan program komputer spesifik yang mahal.

Selain itu hal yang penting dihadapi oleh perusahaan saat ini adalah persaingan. Karena itu diperlukan pemasaran yang berorientasi kepada pelanggan dan dibutuhkan informasi yang memanfaatkan database yang menyimpan transaksi pelanggan untuk melakukan analisis penjualan produk atau jasa dengan teknik data mining dan konsep cross-selling. Di sini perlu mengkombinasikan data hasil survei dengan data transksi pelanggan yang disimpan di dalam database untuk kemudian dihitung probabilistik dan dilakukan prediksi penjualan produk dan jasa perusahaan (Kamakura, Wedel, Rosa, \& Mazzon, 2003). Data warehouse sebagai database yang khusus dirancang untuk mendukung Manajemen Informasi dan Analisa perlu untuk dikembangkan. Data warehouse dapat mengintegrasikan data dari berbagai sumber data yang berbeda dan mengintegrasikan informasi ini di dalam tempat tunggal.

\section{Perumusan Masalah}

Masalah yang dapat dirumuskan pada analisis penjualan produk PT. XYZ terdiri atas bagaimana menghasilkan informasi yang dibutuhkan oleh manager perusahaan mengenai fakta-fakta bisnis seperti pembelian, penjualan dan pembatalan pembelian oleh pelanggan yang terjadi pada suatu periode? Bagaimana memproses data menjadi informasi yang membantu para manager mengambil keputusan? Misalkan laporan penjualan serta produk apa yang paling laku dan informasi lainnya, Bagaimana membantu para manager dalam mengambil keputusan yang cepat dan tepat? Dari ketiga hal tersebut, dapat disimpulkan bahwa dibutuhkan tidak hanya suatu tempat penyimpanan seluruh data transaksi yang terjadi tapi dapat juga menghasilkan laporan yang berguna bagi pemilik perusahaan sebagai bahan pertimbangan untuk menganalisis suatu masalah dan mengambil keputusan.

\section{Tujuan Penelitian}

Tujuan dari penulisan hasil penelitian ini adalah untuk mempelajari dan menjelaskan data warehouse, data mining dan penerapannya untuk pengembangan bisnis dalam hal ini analisis terhadap penjualan produk perusahaan dan peningkatan kinerja perusahaan. Diharapkan Data Warehouse dan data mining dapat membantu perusahaan dalam meningkatkan efektifitas kerja dengan cara mempermudah analisis suatu masalah dan membantu dalam membuat keputusan yang cepat serta tepat berdasarkan informasi yang tersedia. 


\section{Studi Pustaka}

\section{Data Warehouse}

Membuat data warehouse tidak sekedar memindahkan data opersional ke dalam data warehouse, memindahkan data dari beberapa sumber berpotensi menimbulkan masalah besar terutama terkait dengan isu tidak konsistennya data. Data warehouse tidak hanya digunakan dalam melakukan loading, integrasi, dan menyimpan data dalam jumlah besar, namun juga berpotensi untuk mendapatkan sudut pandang baru dari sebaran data, dan memungkinkan untuk memberikan pelaporan dan jawaban dari pertanyaan pengguna yang bersifat ad hoc secara cepat dan lebih baik. Tahapan untuk membangun data warehouse terdiri atas identifikasi sumber data, membangun ETL, ekstraksi, transformasi, dan loading.

\section{Identifikasi sumber data}

Langkah pertama sebelum mulai mengembangkan data warehouse yaitu identifikasi sumber data. Perlu mencari tahu apa data yang dibutuhkan untuk diletakkan ke dalam data warehouse.

\section{Membangun ETL (Extraction, Transformation, Loading)}

Setiap data warehouse memiliki data yang berbeda persyaratan, oleh karena itu, ETL tool yang sesuai adalah solusi yang lebih baik untuk memenuhi persyaratan.

\section{Ekstraksi}

Perlu menentukan sistem database yang akan digunakan dan juga mencari tahu data apa yang diperlukan sebelum mendapatkannya. Penurunan biaya perangkat keras dan penyimpanan telah mengatasi masalah pada menghindari duplikasi data dan juga kekhawatiran pada kurangnya ruang penyimpanan sebagai tempat penyimpanan data yang berlebihan atau yang tidak diperlukan. Namun, mungkin tidak ada alasan untuk menyimpan data yang tidak diperlukan dan telah diidentifikasi tidak berguna dalam proses pengambilan keputusan. Oleh karena itu, diperlukan untuk mendapatkan hanya ekstrak data yang relevan sebelum membawa ke data warehouse (Mallach, 2000).

\section{Transformasi}

Setelah penggalian data dari berbagai sumber, transformasi dibutuhkan untuk menjamin konsistensi data. Agar mengubah data ke dalam data warehouse dengan benar, perlu mengetahui cara pemetaan bidang sumber data eksternal ke data warehouse. Transformasi dapat dilakukan selama ekstraksi data atau saat memuat data ke dalam data warehouse. Integrasi ini bisa menjadi masalah yang kompleks ketika jumlah sumber data menjadi lebih besar.

\section{Loading}

Setelah proses penggalian, mengubah dan pembersihan telah dilakukan, data diambil ke dalam data warehouse. Pemuatan data dapat dikategorikan ke dalam dua jenis; pemuatan data yang saat ini ada dalam database operasional dan pemuatan pembaruan data warehouse dari perubahan yang telah terjadi dalam database operasional. Untuk menjamin kesegaran data, data warehouse perlu untuk terus memperbaharui datanya. Banyak persoalan yang perlu untuk dipertimbangkan terutama saat memuat data yang sudah diperbaharui ke data warehouse. Sementara melakukan pemutakhiran data warehouse, perlu memastikan bahwa tidak ada data yang dilepaskan dan juga untuk memastikan overhead minimum selama proses scanning file yang ada. 


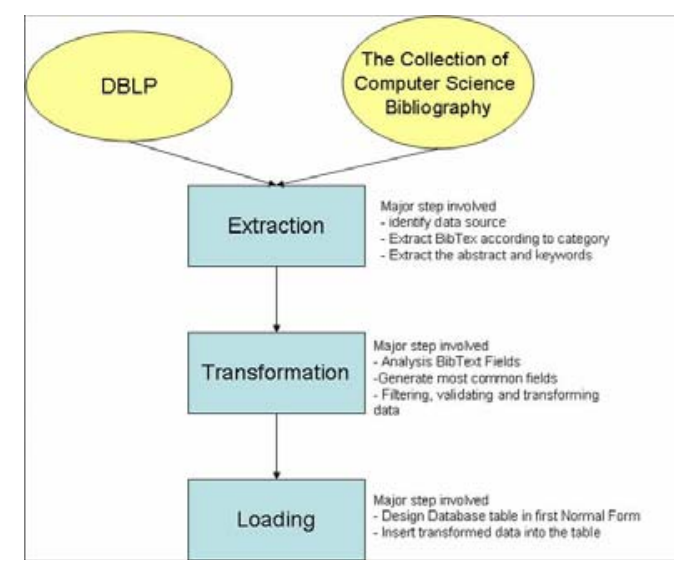

Gambar 1. Tahap-tahap membangun data warehouse Sumber: Wah, Peng \& Hok (2007)

\section{Data Mining}

Data mining (DM) adalah proses mencari dan menggali hubungan antar data yang berguna bagi penggunanya. Data mining (DM) juga merupakan proses mencari data untuk menemukan yang sebelumnya tidak diketahui dari hubungan antara data yang menarik untuk penggunanya (Hand, 1998). Tahap terpenting dalam mendapatkan pengetahuan dari dalam database adalah data mining. DM telah menjadi bidang ilmu tersendiri (Fayyad, Piatetsky-Shapiro \& Smyth, 1996; Chen \& Liu, 2005). Data mining adalah subjek yang terus berkembang (Chen \& Liu, 2005) di mana digunakan untuk mendapatkan pengetahuan (knowledge discovery) dari dalam database yang mengacu pada keseluruhan proses mulai dari low-level data sampai ke high-level data. Data mining adalah proses untuk menemukan suatu pola dan trend dari data. Tujuan dari proses ini adalah menyusun data yang berjumlah besar untuk mendapatkan informasi baru. Data mining juga dapat berarti eksplorasi dan analisis data secara otomatis atau semi otomatis dari data yang jumlahnya besar untuk mendapatkan pola dan aturan yang bermakna bagi penggunanya (Fayyad, Piatetsky-Shapiro \& Smyth, 1996). Chang \& Chen (2006) dan Yu \& Chen (2001) menjelaskan bahwa proses data mining terdiri atas enam proses kerja utama yang dapat dilihat pada Gambar 2.

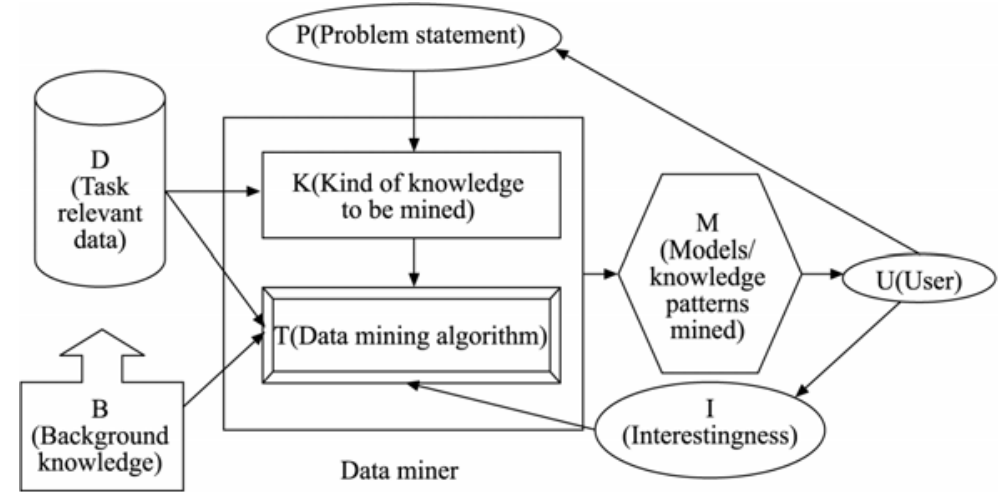

Gambar 2. Proses kerja data mining

Sumber : Chang \& Chen (2006)

Data mining adalah proses mencari tren dan pola dalam data. Tujuan dari proses ini adalah untuk menyortir besar jumlah data dan menemukan informasi baru. Manfaat dari data mining adalah 
pengetahuan baru ditemukan dan hasil ditindaklanjuti. Tujuan dari data mining adalah untuk mengekstrak informasi yang berharga dan baru dari data yang ada. Secara umum, data mining meliputi fungsi utama, yaitu: Klasifikasi, Clustering, Estimasi, Prediksi, dan Deskripsi.

Teknologi data mining dapat dibagi antara teknologi tradisional dan halus. Statistik analisis merupakan perwakilan dari teknologi tradisional. Adapun teknologi data mining halus adalah semua jenis kecerdasan buatan yang digunakan, yang lebih sering digunakan adalah jenis pohon keputusan, jaringan syaraf, algoritma genetika, logika fuzzy dan aturan induksi. Penggunaan berbagai jenis aplikasi yang berbeda sering dapat menyebabkan hasil yang berbeda.

Han \& Kamber (2001), dan Buja \& Lee (2001), model data mining yang umum digunakan adalah (1) classification, mengklasifikasikan item data ke dalam salah satu dari beberapa standar kategoris kelas; (2) regression, memetakan sebuah item data ke sebuah variabel nilai prediksi nyata; (3) clustering, memetakan sebuah item data ke dalam salah satu dari beberapa cluster, dimana cluster mengelompokan item data berdasarkan matrik kesamaan atau model kepadatan probabilitas; (4) rule generation, ekstrak aturan klasifikasi dari data; (5) discovering association rule, asosiasi menggambarkan hubungan antara berbagai atribut; (6) summarization, memberikan gambaran solid untuk subset data; (7) dependency modelling, menggambarkan dependensi yang signifikan antara variabel.

\section{Star Schema}

Star schema merupakan paradigma modeling yang paling banyak digunakan, di mana di dalamnya mengandung antara lain sebuah tabel pusat yang besar tanpa adanya data redundancy di dalamnya, yang biasa disebut dengan tabel fakta. Selain itu, di dalam star schema juga mengandung satu set tabel yang lebih kecil, yang biasa disebut dengan tabel dimensi. Berikut adalah beberapa karakteristik utama dari star schema antara lain: pusat dari star schema adalah tabel fakta, tabel fakta berisi indikator-indikator kinerja pokok, objek-objek informasi dan waktu adalah kunci utama tabel fakta, tabel-tabel yang ada di sekeliling tabel fakta adalah tabel dimensi, tabel dimensi berisi data mengenai objek-objek informasi atau waktu, tabel fakta dan tabel dimensi direlasikan dengan key yang ada, Star scheme diimplementasikan menggunakan teknologi relational database.

\section{Cross-Selling}

Sebuah aspek penting dari orientasi baru pada pemasaran berorientasi pelanggan adalah penggunaan database transaksi pelanggan untuk analisis menjual-silang (cross-selling) layanan dan produk. Cross-selling berkaitan dengan upaya peningkatan jumlah produk atau jasa yang pelanggan gunakan atau beli dari perusahaan. Cross-selling produk dan jasa yang dibeli pelanggan saat ini memerlukan biaya lebih rendah dari biaya yang terkait untuk memperoleh pelanggan baru, karena perusahaan sudah memiliki hubungan dengan pelanggan. Implementasi yang tepat dari pelaksanaan cross-selling hanya dapat dicapai jika ada suatu infrastruktur informasi yang memungkinkan manajer untuk menawarkan produk atau layanan kepada pelanggan yang menyerap kebutuhan mereka tetapi belum dijual kepada mereka (Kamakura, Wedel, Rosa \& Mazzon, 2003). Pada prinsipnya, strategi pemasaran cross-selling adalah sebuah istilah umum yang digunakan untuk menjelaskan penjualan tambahan produk atau layanan kepada pelanggan yang telah membeli sesuatu dari perusahaan. Strategi ini berhubungan dengan analisis data pelanggan.

Dengan menganalisa perilaku pelanggan, dapat dimungkinkan untuk memperkirakan model perilaku pelanggan selanjutnya dan juga perilaku pelanggan mana yang potensial. Hal ini sangat menguntungkan bagi perusahaan karena dapat menjual produk dan layanan yang berbeda dengan menggunakan teknik pemasaran yang lebih beragam melalui pengetahuan (knowledge) yang telah diperolehnya. Perusahaan dapat mengidentifikasi kebutuhan dan keinginan pelanggan untuk 
menetapkan additional product dari produk utamanya. Additional product yang disarankan dapat berupa common-sense-based (contohnya, jika pelanggan membeli sebuah kamera digital, maka crosssell product-nya biasanya adalah memory card, case, dan spare-battery) atau dapat pula berupa datadriven (cross-selling didapat dari data pembelian historikal pelanggan). Cross-selling biasanya digunakan oleh sebagian besar online store untuk menentukan rekomendasi produk apa yang seharusnya dijual juga. Sebagai contoh dapat dilihat salah satu online bookstore terkemuka seperti Amazon.com dapat dengan jelas terlihat bahwa jika seorang pelanggan membeli buku secara online maka website akan memberikan pula rekomendasi mengenai buku yang terkait yang direkomendasikan untuk dibeli. Hal ini dapat dilakukan melalui analisis.

\section{Database Pemasaran}

Database pemasaran melibatkan pembangunan, pengorganisasian, melengkapi, dan menggali transaksi pelanggan untuk meningkatkan akurasi dari upaya pemasaran dan memungkinkan identifikasi prospek terbaik untuk upaya pemasaran (Goodman, 1992).

\section{METODE}

Tahapan yang dilakukan untuk mengembangkan dan implementasi data warehouse, teknik data mining dan cross-selling dalam penelitian ini terdiri dari (1) studi literatur, mengumpulkan dan mempelajari bahan-bahan yang diperlukan untuk pembuatan data warehouse; (2) analisis perusahaan, mengumpulkan data dari perusahaan yang dibutuhkan dalam pembuatan data warehouse dengan melakukan wawancara dan pengamatan secara langsung ke perusahaan dan melakukan analisis terhadap sistem basis data yang dijalankan oleh perusahaan; (3) perancangan data warehouse, membuat Rancangan Entity Relationship Diagram (ERD), Menetapkan tabel tabel yang digunakan dalam data warehouse dan Membuat rancangan Star Schema; (4) pengujian hasil, melakukan pengujian terhadap rancangan data warehouse dan data mining telah selesai dibuat sehingga dapat diketahui apakah telah berjalan sesuai dengan harapan dan tujuan yang ingin dicapai; (5) kesimpulan, setelah pengujian sudah selesai dilakukan dan diperoleh hasil yang diinginkan, maka hasil dapat diterapkan.

\section{HASIL DAN PEMBAHASAN}

\section{Analisis Kebutuhan}

Pada fase ini mendefinisikan semua sumber data yang digunakan dalam data warehouse dan mendefiniskan kebutuhan informasi yang harus dihasilkan oleh data warehouse melalui analisis reporting.

\section{Kebutuhan Sumber Data}

Sumber data yang digunakan dalam data warehouse adalah data yang ada dalam database operasional yang terdiri atas tabel MsBuku, MsCabang, MsAksesoris, MsJenisBuku, MsJenisKaryawan, MsJilidBuku, MsKaryawan, MsPelanggan, MsProvinsi, MsSupplier, DetailPembelianAksesoris, DetailPembelianBuku, DetailPenjilidan, DetailPenjualanAksesoris, DetailPenjualanBuku, HeaderPembelianAksesoris, HeaderPembelianBuku, HeaderPenjilidan, Tabel HeaderPenjualanAksesoris, dan Tabel HeaderPenjualanBuku. 


\section{Kebutuhan Informasi}

Informasi yang dibutuhkan oleh pihak manajemen untuk mendukung analisis dalam mengambil keputusan terdiri atas tren terhadap buku yang dibeli oleh pelanggan, Informasi mengenai jenis buku yang sering dibeli, tren proses pembelian oleh pelanggan, tren terhadap aksesoris yang dibeli pelanggan, dan tren terhadap pembelian buku dan aksesoris yang dibeli oleh pelanggan.

\section{Perancangan Data Warehouse}

Data yang digunakan untuk membangun data warehouse berasal dari database operasional. Adapun gambar Entity Relationship Diagram (ERD) dari database yang digunakan dapat dilihat pada Gambar 3 dibawah ini:

\section{Model Data Dimensional}

Berdasarkan Entity Relationship Diagram (ERD) dan kebutuhan informasi yang dibutuhkan oleh manajemen maka dibuat model data dimensional dalam bentuk star schema untuk data warehouse. Star schema tersebut terdiri atas tabel dimensi, yaitu dimensi waktu, dimensi supplier, dimensi provinsi, dimensi aksesoris, dimensi cabang dan dimensi karyawan; dan tabel fakta yaitu fakta pembelian buku dan asesoris.

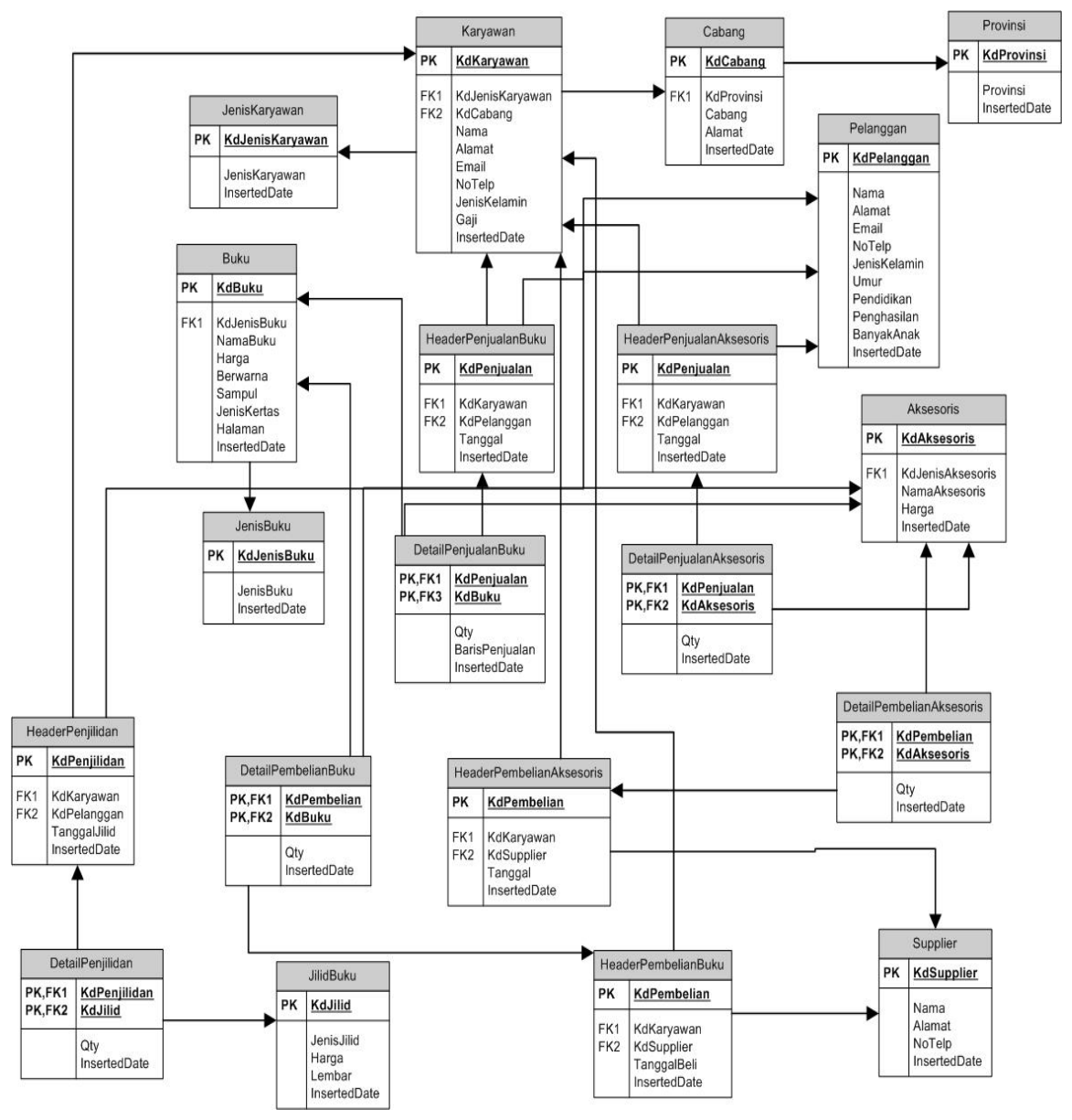

Gambar 3. Entity Relationship Diagram (ERD) 


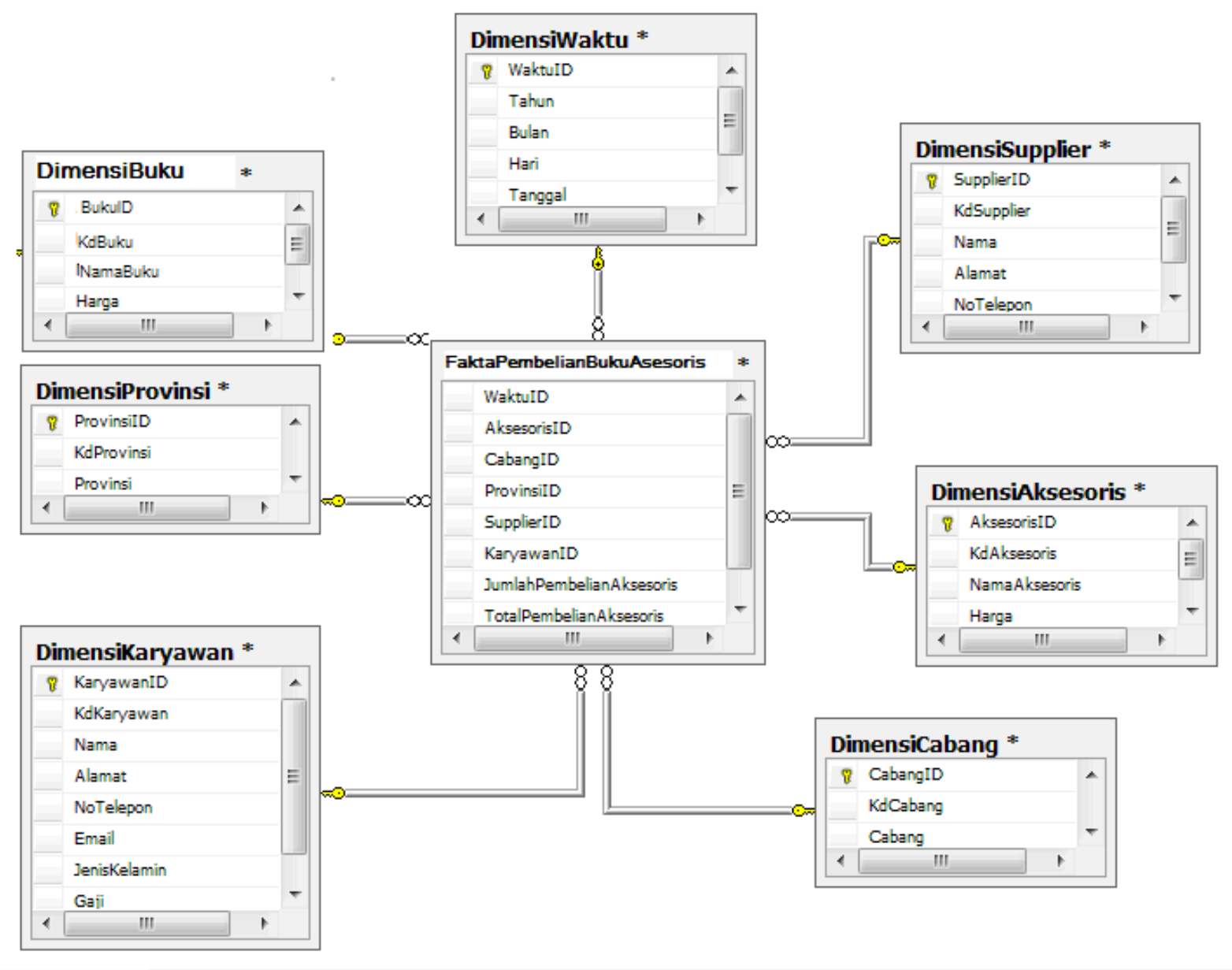

Gambar 4. Star Schema untuk data warehouse

\section{Desain Proses ETL}

Proses selanjutnya setelah star schema dibuat adalah membuat desain proses ETL (Extraction, Transformation dan Loading). Desain proses ETL, seperti pada Gambar 5, yang dipakai bisa dilihat pada gambar dibawah ini. Proses ETL mengambil data dari source systems menggunakan query. Setelah data hasil query diambil langkah selanjutnya dilakukan eksekusi proses ETL dan mengirimnya ke database data warehouse.

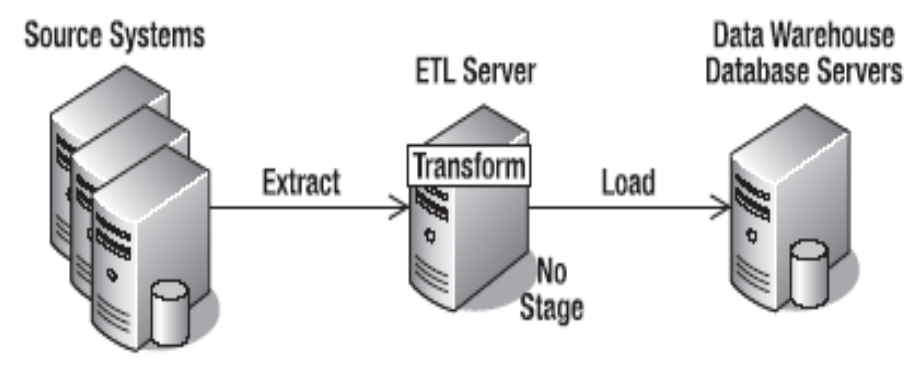

Gambar 5 Desain proses ETL 


\section{Pengujian Hasil}

\section{Penentuan Cross-Selling}

Pemilihan produk didasarkan pada frekuensi (seberapa sering) kemunculan produk selama periode transaksi berlangsung. Dari data frekuensi tersebut, kemudian akan ditentukan tiga indikator yang berbeda untuk menghasilkan kemungkinan cross-selling yang paling baik. Tiga indikator tersebut adalah support score, confidence score, dan improvement score. Support score mengindikasikan seberapa sering dua produk muncul bersama-sama di dalam suatu periode transaksi, confidence score mengindikasikan seberapa banyak sebuah produk tertentu tergantung dengan produk yang lain, dan improvement score menunjukkan seberapa besar kemungkinan pelanggan yang lebih menyukai untuk membeli produk kedua (dalam hal ini cross-selling product) yang diberikan pada saat membeli produk pertama (base product).

Kemungkinan untuk menghasilkan cross-selling product yang terbaik dari total transaksi per pelanggan pada periode tertentu adalah item dengan confidence score yang tinggi. Jadi misalkan produk pertama adalah kombinasi A dan B dengan confidence score $\mathrm{x} \%$ berarti bahwa ketika produk A dibeli, kemungkinan produk B juga dibeli sebesar $\mathrm{x} \%$ dari seluruh periode transaksi.

Indikator kedua yang harus ditentukan adalah support score yang menentukan seberapa banyak produk A dan produk B muncul bersama-sama di dalam seluruh transaksi. Misalkan kombinasi produk $\mathrm{C}$ dan $\mathrm{D}$ memiliki support score $\mathrm{y} \%$ mengindikasikan bahwa produk $\mathrm{C}$ dan produk $\mathrm{D}$ muncul secara bersama-sama sebesar $\mathrm{y} \%$ dari seluruh total transaksi, sedangkan untuk kombinasi produk $\mathrm{E}$ dan F misalnya memiliki improvement score $\geq 1$, mengindikasikan bahwa produk $\mathrm{E}$ dan $\mathrm{F}$ merupakan positive correlated, yang berarti bahwa jika pelanggan membeli produk E, pelanggan juga setuju untuk membeli produk $\mathrm{F}$, sedangkan jika improvement score $<1$, produk $\mathrm{E}$ dan $\mathrm{F}$ merupakan negative correlated. Produk dengan negative correlated tidak dapat dijadikan sebagai saran dalam penetapan cross-selling product walaupun memiliki support score dan confidence score yang tinggi.

Setelah dilakukan proses pencarian asosiasi antara produk yang satu dengan produk yang lain dari dataset yang ada maka diperoleh sekumpulan rules dan itemset seperti tampak pada Gambar 6 . Dengan mengacu kepada pemodelan dalam menentukan cross-selling product di atas, maka dari seluruh kombinasi yang ada, seluruh rules yang mengandung kombinasi dua produk akan diteliti, namun hanya kombinasi yang mengandung unsur masing-masing produk yang menduduki peringkat 20 teratas sebagai produk pertama dari kombinasi tersebut yang akan digunakan selanjutnya.

Sesuai dengan kriteria penetapan cross-selling product yang terbaik, maka improvement score ditetapkan harus lebih besar atau sama dengan satu, karena improvement score kurang dari satu mengindikasikan pelanggan yang membeli base product tidak setuju untuk membeli cross-selling product yang disarankan, dan saran cross-selling product untuk masing-masing 20 produk tersebut akan dipilih dan diurutkan berdasarkan confidence score-nya. Dari tabel tersebut confidence score dan improvement score-nya masing-masing dinyatakan dalam persen, sedangkan support score dinyatakan dengan nilai yang mengindikasikan jumlah transaksi antara produk pertama (base product) dan crossselling product dari total seluruh transaksi yang ada. 


\begin{tabular}{|c|c|c|}
\hline S Sugxacat & Sien & inemset \\
\hline 167 & 2 & FILM WARNA NEW SUPERIA X TRA 400/36, FILM WAREA NEW/ SUPERIA $200 / 36$ \\
\hline 146 & 2 & RLM FUICOLLO 200. FLM WAMNA NCW SUPENU 200/36 \\
\hline 123 & 2 & AMFLOP FIS. FILM WARNA NEW SUPERLA $200 / 36$ \\
\hline 120 & 2 & FUM WARMA NEW SUPERIA $200 / 20$, FIUM WARNA NEW SUPERIA $200 / 36$ \\
\hline 117 & 2 & FLM FUNICOLOA 200 . FLM WAPRLA NEW SUPERLAX,TRA $400 / 36$ \\
\hline 115 & 2 & 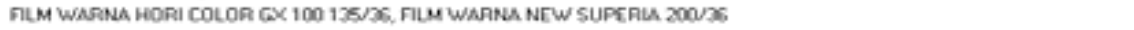 \\
\hline 112 & 3 & FLM FUICOLOR 200 . FLM WAFNA NEW SUPERIAX,TRA SO0/36. FILM WARNA NEW SUPERLA $200 / 36$ \\
\hline 101 & 2 & FILM WARNA NEW SUPERIA $200 / 20$, FIUM W/ARIAA NEW SUPERIAX TRA $400 / 36$ \\
\hline 90 & 2 & AMFLOP FIS, FILM WAANA NEW SUPEALA X-TRA $400 / 36$ \\
\hline 97 & 3 & 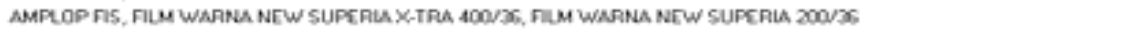 \\
\hline 94 & 3 & 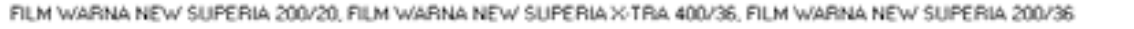 \\
\hline 93 & 2 & FLM WARNA PRO PLUS [3 ROLLI] FILM WARNA NEW SUPERLA $200 / 36$ \\
\hline 92 & 2 & AMFLOP AS, FLM RUICOLOA 200 \\
\hline 91 & 2 & FLM WARNA NEW SUPERLA $200 / 20$. FUM FUICOLOR 200 \\
\hline 90 & 3 & AMPLOP FIS, FILM FUUICOLOR 200 , FIUM WAARA NEW SUPERLA $200 / 3$ \\
\hline 69 & 3 & FLM WAPNA NEW SUPEPLA $200 / 20$, FIM FUICOLOA 200 , FLM WAARAA NEW SUPERLA $200 / 36$ \\
\hline 97 & 2 & 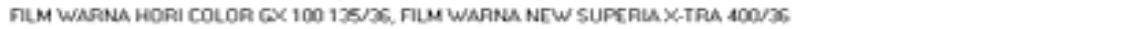 \\
\hline$\$$ & 2 & FLM WARNA HORI COLOR GX $100135 / 36$. FILM FUUCOLOR 200 \\
\hline 83 & 3 & FILM WARNA HORI COLOR GX 100 135/36, FILM FUICOLOR 200 , FILM W/ARNA NEW SUPERLA $200 / 36$ \\
\hline 01 & 2 & CAYSTAL $005 \times 610$ G. AMPLOP AS \\
\hline 81 & 2 & CRYSTAL B0 $5 \times 610$ G, FLM WARNA NEW SUPERLA 200/36 \\
\hline \$1 & 3 & FLM WAARA HORI COLOR GX $100135 / 36$. FILM WAARA NEW SUPEALA X.TRA 400/36, FILM W/APANA NEW SUPERIA $200 / 36$ \\
\hline en & 2 & ESO123 CN-160 NQ1P 1QLTCZ, FUM WAANA NEEW SUPEALA $200 / 36$ \\
\hline 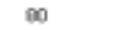 & 2 & ASO123 CN-162 NQ1R 1QLTYQ, AMPLOP FIS \\
\hline$\infty$ & 3 & CFYSTAL $805 \times 610 \mathrm{G}$. AMPLOP FIS. FIUM WAANA NEW SUPEALA ZOO/36 \\
\hline 79 & 3 & AMPLOP FIS, FILM FUNCOLOR 200 , FILM W/ARNA NEW SUPEALA X.TRA 400/36 \\
\hline ra & 3 & 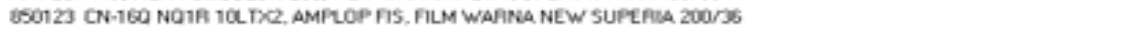 \\
\hline 77 & 3 & 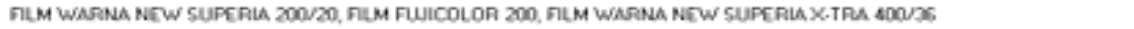 \\
\hline 77 & 2 & 850006 CN-16Q NQ3A \&LTX2. 850123 CN-16Q NQ1R 1QLTX2 \\
\hline$n$ & 2 & S50006 CN.160 NQSA \&LTC2, FILM WARNA NEW SUPERLA $200 / 36$ \\
\hline$\pi 6$ & 2 & 050006 CN-160 NQSA QLT:2, AMPLOP FIS \\
\hline 75 & 2 & 850045 CN-16O NO2R \&L TXQ. FIUM WARANA NEW SUPERLA $200 / 35$ \\
\hline$\pi 5$ & 3 & \$50006 CN.160 NQ3A \&LIX2, AMPLOP FIS, FLM WAARA NEW SUPERIA $200 / 36$ \\
\hline
\end{tabular}

Gambar 6. Itemset yang Dihasilkan

\begin{tabular}{|c|c|c|}
\hline$\nabla$ Probability & Importance & Rule \\
\hline 1.000 & 1.178 & KAMERA, AVEC, FILM WARNA NEW SUPERIAX-TRA 400/36 -> SLING BAG \\
\hline 0.986 & 1.166 & 850045 CN-16Q NQ2R 8LTX2, 850006 CN-16Q NQ3R 8LTX2 > 850123 CN-16Q NQ1R 10LTX2 \\
\hline 0.981 & 1.168 & KAMERA AVEC $\rightarrow$ SLING BAG \\
\hline 0.980 & 1.123 & KAMERA, AVEC, FILM WARNA NEW SUPERIA, 200/36 -> SLING BAG \\
\hline 0.974 & 1.072 & CP47 P1R, FILM WARNA NEW SUPERIA 200/20 -> CP47 P2R \\
\hline 0.972 & 1.133 & 850045 CN-16Q NQ2R 8LTX2, AMPLOP FIS >> 850123 CN-16Q NQ1R 10LTX2 \\
\hline 0.963 & 1.390 & 850006 CN-16Q NQ3R 8LTX2 -> 850123 CN-16Q NQ1R 10LTX2 \\
\hline 0.962 & 1.102 & CRYSTAL $806 \times 610 L$, CRYSTAL $808 \times 295 \mathrm{~L} \rightarrow$ CP49E REPL \\
\hline 0.961 & 1.269 & 850006 CN-16Q NQ3R 8LTX2, FILM WARNA NEW SUPERIA 200/36 $\Rightarrow 850123$ CN-16Q NQ1R 10LTX2 \\
\hline 0.961 & 1.269 & $850045 \mathrm{CN}-16 \mathrm{Q}$ NQ2R 8LTX2 $>850123 \mathrm{CN}-16 \mathrm{Q}$ NQ1R $10 \mathrm{LT} \times 2$ \\
\hline 0.961 & 1.236 & 850006 CN-16Q NQ3R 8LTX2, AMPLOP FIS -> 850123 CN-16Q NQ1R 10LTX2 \\
\hline 0.960 & 1.205 & 850045 CN-16Q NQ2R 8LTX2, FILM WARNA NEW SUPERIA 200/36 -> 850123 CN-16Q NQ1R 10LTX2 \\
\hline 0.959 & 1.280 & CP47 P1R, FILM WARNA NEW SUPERIAX-TRA 400/36 -> CP47 P2R \\
\hline 0.957 & 1.250 & CP47 P2R, FILM FUJICOLOR 200 -> CP47 P1R \\
\hline 0.957 & 1.142 & $\mathrm{VIO}+\mathrm{BATT}+\mathrm{NS}$ 400/36+FB, AMPLOP FIS $>$ RIO+BATT+NS 400/36+FB \\
\hline 0.957 & 1.193 & CP47P1R, 850006 CN-16Q NQ3R 8LTX2 > CP47 P2R \\
\hline 0.957 & 1.193 & CP47 P1R, 850123 CN-16Q NQ1R 10LTX2 $>$ CP47 P2R \\
\hline 0.956 & 1.194 & CP47 P2R, 850045 CN-16Q NQ2R 8LTX2 -> CP47 P1R \\
\hline 0.956 & 1.167 & CP47 P1R, 850045 CN-16Q NQ2R 8LTX2 -> CP47 P2R \\
\hline 0.952 & 1.058 & $\mathrm{VIO}+\mathrm{BATT}+\mathrm{NS}$ 400/36+FB, FILM FUJICOLOR $200->\mathrm{RIO}+\mathrm{BATT}+\mathrm{NS}$ 400/36+FB \\
\hline 0.952 & 1.122 & CP47 P2R, CRYSTAL $805 \times 610 \mathrm{G} \cdot>\mathrm{CP} 47 \mathrm{P} 1 \mathrm{R}$ \\
\hline 0.949 & 1.005 & VIO+BATT+NS 400/36+FB, FILM WABRNA NEW SUPERIA, 200/20 -> RIO+BATT+NS 400/36+FB \\
\hline 0.948 & 1.676 & CP47 P1R, FILM W/ARNA NEW/ SUPERIA, 200/36 -> CP47 P2R \\
\hline 0.948 & 1.773 & CP47 P2R, FILM W/ARNA NEW/ SUPERIA, 200/36 $>$ CP47 P1R \\
\hline 0.948 & 1.676 & CP47 P1R, AMPLOP FIS -> CP47 P2R \\
\hline 0.948 & 1.676 & $\mathrm{CP} 47 \mathrm{P} 1 \mathrm{R}->\mathrm{CP} 47 \mathrm{P} 2 \mathrm{R}$ \\
\hline 0.946 & 1.306 & 850045 CN-16Q NQ2R 8LTX2,850123 CN-16Q NQ1R 10LTX2 -> 850006 CN-16Q NQ3R 8LTX2 \\
\hline 0.944 & 1.007 & CP47 P2R, CRYSTAL $808 \times 295 \mathrm{~L}>$ CP47 P1R \\
\hline 0.944 & 1.205 & 850045 CN-16Q NQ2R 8LTX2, AMPLOP FIS -> 850006 CN-16Q NQ3R 8LTX2 \\
\hline 0.940 & 1.304 & CP47 P2R, FILM WARNA NEW SUPERIAX-TRA 400/36 -> CP47 P1R \\
\hline 0.938 & 1.209 & CP47 P1R, FILM FUJICOLOR 200 -> CP47 P2R \\
\hline 0.937 & 1.083 & 850006 CN-16Q NQ3R 8LTX2, FILM WARNA NEW SUPERIAX-TRA, 400/36 -> 850045 CN-16Q NQ2R 8LTX2 \\
\hline 0.933 & 1.587 & $\mathrm{VIO}+\mathrm{BATT}+\mathrm{NS} 400 / 36+\mathrm{FB} \rightarrow \mathrm{RIO}+\mathrm{BATT}+\mathrm{NS} 400 / 36+\mathrm{FB}$ \\
\hline
\end{tabular}

Gambar 7. Rules yang Dihasilkan 


\section{PENUTUP}

Database yang menyimpan data transaksi penjualan tidak dapat mendukung analisa data dan pengambilan keputusan. Data transaksi penjualan yang ada dapat digunakan untuk analisis dengan menggunakan perangkat bantuan business intelligence yang ada dengan menentukan jumlah data yang dilibatkan dan penyesuaian terhadap format datanya. Data warehouse dapat digunakan untuk menyimpan data dalam jumlah besar dan juga berpotensi untuk mendapatkan sudut pandang baru dari sebaran data, dan memungkinkan untuk memberikan pelaporan dan jawaban dari pertanyaan pengguna yang bersifat ad hoc termasuk juga untuk melakukan analisis penjualan dengan konsep cross-selling untuk mendukung pengambilan keputusan.

Proses transformasi dari database yang menyimpan data transaksi penjualan mampu memindahkan data penting yang berguna bagi perusahaan untuk melakukan analisis. Star Schema yang telah dirancang dapat memenuhi fungsinya sebagai suatu tempat penampungan data yang memungkinkan para pengambil keputusan untuk pergi hanya ke satu tempat untuk mengakses seluruh data yang ada tentang organisasinya. Metode cross-selling dilakukan dengan memilih produk didasarkan pada frekuensi (seberapa sering) kemunculan produk selama periode transaksi berlangsung. Terdapat tiga indikator untuk menghasilkan kemungkinan cross-selling yang paling baik. Support score, confidence score, dan improvement score. Implementasi data warehouse, teknik data mining dan konsep cross-selling dapat membantu perusahaan menyimpan seluruh data data transaksi, melakukan analisis dan menghasilkan laporan yang berguna bagi perusahaan sebagai bahan pertimbangan untuk menganalisis suatu masaah dan mengambil keputusan.

\section{DAFTAR PUSTAKA}

Buja, A., \& Lee, Y. (2001). Data mining criteria for tree-based regression and classification, Proceedings of the Seventh ACM SIGKDD International Conference on Knowledge Discovery and Data Mining San Francisco, CA, pp. 27-36.

Chang, C. C., \& Chen, R. S. (2006). Using Data Mining Technology to Solve Classification Problems: a Case Study of Campus Digital Library. The Electronic Library Vol. 24 No. 3, pp. 307-321, Emerald Group Publishing Limited.

Chen, S. Y., \& Liu, X. (2005). Data Mining from 1994 to 2004: an Application-Oriented Review. International Journal of Business Intelligence and Data Mining, Vol. 1 No. 1, pp. 4-11.

Fayyad, U., Piatetsky-Shapiro, G., \& Smyth, P. (1996). The KDD Process for Extracting Useful Knowledge from Volumes Of Data. Communications of the ACM, Vol. 39 No. 11, pp. 7-34.

Goodman, J. (1992). Leveraging the customer database to your competitive advantage. Direct Marketing, 55(8), 26- 27.

Han, J., \& Kamber, M. (2001). Data Mining: Concepts and Techniques. San Mateo, CA: Morgan Kaufmann.

Hand, D. J. (1998). Data mining: statistics and more? The American Statistician, Vol. 52 No. 2, pp. $112-8$. 
Kamakura, W. A., Wedel, M., Rosa, F., \& Mazzon, J. A. (2003). Cross-Selling through Database Marketing: a Mixed Data Factor Analyzer for Data Augmentation and Prediction. International Journal of Research in Marketing, 20, 45-65.

Mallach, E. G. (2000). Decision Support and Data Warehouse Systems. United States: McGraw-Hill.

Wah, T. Y., Peng, N. H., \& Hok, C. S. (2007). Building Data Warehouse. Proceedings of the 24th South East Asia Regional Computer Conference 2007, Bangkok, Thailand.

Yu, S. C., \& Chen, R. S. (2001). Developing an XML Framework for an Electronic Document Delivery System. The Electronic Library, Vol. 19 No. 2, pp. 102-10. 